\title{
PENYULUHAN STRATEGI PEMASARAN JAJANAN PASAR PADA KELOMPOK UKM DI DESA KARANGPANDAN, KECAMATAN KARANG PANDAN, KABUPATEN KARANGANYAR
}

\section{TREATMENT OF JAJAN PASAR MARKETING STRATEGY IN KELOMPOK UKM IN KARANG PANDAN VILLAGE, KECAMATAN KARANG PANDAN, KABUPATEN KARANGANYAR}

Dra. Endah Nawangsasi, M.M

Program Studi Akuntansi STIE AUB

nawangsasiendah@yahoo.com

\begin{abstract}
ABSTRAK
Kegiatan pengabdian kepada masyarakat yang dilaksanakan di daerah Karang Pandan, Kecamatan Karang Pandan, Kabupaten Karanganyar, bertujuan memberikan ketrampilan yang dapat meningkatkan taraf hidup masyarakat disekitar khususnya di Desa Karang Pandan, Kecamatan Karang Pandan, Kabupaten Karanganyar. Kegiatan pengabdian kepada masyarakat ini dilaksanakan dalam interval waktu 10 bulan, dan bulan pertama digunakan untuk survey dan persiapan proposal, dua bulan berikutnya untuk pelaksanaan, dan bulan terakhir untuk pelaporan dan pertanggung jawaban. Kegiatan ini mulai direncanakan awal November 2017 hingga bulan Maret 2018. Peserta kegiatan pengabdian kepada masyarakat ini adalah kelompok UKM yang terdiri dari para ibu - ibu PKK di Karang Pandan yang bergabung dalam pembinaan kampus pemberdayaan perempuan. Kebanyakan para peserta berpendidikan rendah (SD, SMP), maka metode yang digunakan adalah melalui pelatihan. Kegiatan pengabdian kepada masyarakat STIE AUB mempunyai target utama : Para peserta dapat merasakan produk yang dibuat sehingga mempunyai nilai jual tinggi yang akhirnya dapat meningkatkan taraf hidup masyarakat Karang Pandan, Kecamatan Karang Pandan, Kabupaten Karanganyar.

Kata kunci : Strategi Pemasaran, Keberhasilan Bisnis
\end{abstract}

\section{ABSTRACT}

Community service activities carried out in the Karang Pandan area, Karang Pandan District, Kabupaten Karanganyar, aimed to provide skills that could improve the living standards of the surrounding community, especially in Karang Pandan Village, Karang Pandan District, Kabupaten Karanganyar. Community service activities are carried out within 10 months, and the first month is used for survey and preparation of proposals, the next two months for implementation, and the last month for reporting and accountability. This activity is planned for early November 2017 until March 2018. The participants of this community service activity were the SME group consisting of PKK mothers in Cinderejo Kidul who joined the campus in empowering women. Most participants have low education (elementary, junior high school), then the method used is through training.

Community service activities at STIE AUB have a main target: Participants can feel the products made so that they have high selling value which ultimately can improve the living standards of the Karang Pandan community, Karang Pandan District, Kabupaten Karanganyar.

Keywords: Marketing Strategy, Business Success 


\section{PENDAHULUAN}

Dipandang dari Ilmu Marketing, pemasaran yang berhasil adalah yang dapat memenuhi kebutuhan konsumen. Dalam pengertian teknis, hal ini berarti bahwa setiap pelaku pemasaran harus dapat menciptakan suatu komoditi yang mutunya sesuai dengan kegiatan indentifikasi kebutuhan dan keinginan konsumen, menentukan jenis bentuk dan penentuan pola distribusi atau penyaluran barang dan jasa. Kegiatan pemasaran tersebut merupakan suatu system yang terpadu antara kegiatan yang satu dengan yang lain.

Ekonomi yang maju dalam masyarakat tidak langsung muncul. Kemajuan Ekonomi dan Kesejahteraan Ekonomi tidak hanya monopoli kaum terdidik atau kaum kelas atas, namun menjadi hak semua lapisan masyarakat, termasuk kaum marginal atau kaum pinggiran.

Kesejahteraan Ekonomi rakyat harus diawali dari rakyat itu sendiri, yaitu dengan memberdayakan rakyat, seperti munculnya usaha mikro, menengah, dan kecil, yang sering disebut istilah UMKM. UMKM inilah yang menjadi dasar strategis memperkuat Ekonomi Kerakyatan, karena hal tersebut dapat membuka lapangan pekerjaan yang dapat mengurangi kemiskinan.

UMKM merupakan solusi untuk memecahkan masalah kemiskinan, karena masyarakat Ekonomi lemah akan lebih berani dan termotivasi untuk berusaha memperbaiki kehidupannya dengan mengadakan usaha dagang. Oleh karena itu UMKM harus membuka selebar - lebarnya dalam memberi peluang usaha pada masyarakat ekonomi lemah misalnya membuka peluang dan penyuluhan/pelatihan Sumber Daya Manusia untuk menjadi SDM yang terlatih di dunia bisnis dengan melatih ketrampilan, yang akhirnya termotivasi menjadi seorang wirausaha (Entrepreuneruship) dan membantu bagaimana cara memasarkan produknya.

Pemberdayaan UMKM bisa dilakukan melalui pemberdayaan masyarakat, oleh karena itu pemberdayaan UMKM harus dilakukan secara terencana, sistematis, komprehensif baik secara mikro maupun makro. Pemberdayaan UMKM secara sistematis harus dibarengi peningkatan UKM usaha yang luas sehingga akan terbentuk jiwa kewirausahaan di masyarakat.

Demikian pula perlu diberi pemahaman IPTEK pada calon wirausaha agar setiap proses produksi sehingga dapat memperkuat efisiensi biaya.

Keahlian dan ketrampilan serta kreatifitas seorang dapat diajarkan melalui bangku sekolah formal, namun juga dapat diajarkan dibangku non formal. Ketrampilan dan bakat seseorang yang sudah ada perlu diasah melalui bentuk - bentuk pelatihan - pelatihan. Namun saying tidak banyak masyarakat yang beruntung menikmati bangku sekolah, karena ketidakmampuan untuk membiayai sekolah, dan pendapatan keluarga yang pas-pasan sehingga tidak akan dapat mengembangkan usaha atau memulai suatu usaha. Kelompok miskin makin tertekan dan tersisih.

Hal inilah yang harus mendapat perhatian dari pemerintah untuk memberikan pelatihan-pelatihan melalui lembaga-lembaga yang memberikan pelatihan-pelatihan ketrampilan gratis, sehingga akan muncul wirausaha baru, misalnya pelatihan-pelatihan perhitungan modal usaha, pelatihan cara pemasarannya.

Dengan terbentuknya UMKM, maka akan memperkuat Ekonomi keluarga-keluarga, terutama di masyarakat pedesaan yang mulai kehilangan pendapatan karena banyak lahan kehidupan dari bercocok tanam semakin menyempit diganti dengan munculnya pabrikpabrik.

Menjadi wirausaha adalah suatu pilihan, suatu proses pengambilan keputusan, menjadi wirausaha adalah kesempatan bagi siapa saja untuk dapat berhasil dalam dunia perdagangan. Menjadi wirausaha tidak harus memerlukan modal banyak, namun lebih dari itu ada yang lebih penting adalah reputasi, kepercayaan, prestasi, kreativitas, serta kejujuran. 
Seorang wirausaha harus dapat berpikir terbuka, berorientasi kedepan dan mampu menghasilkan ide-ide baru dan mampu berpikir serta berbeda dari yang lain. UMKM harus dapat memberikan motivasi bagaimana menjadi wirausaha yang ulet, tidak mudah menyerah, karena sekarang makin banyak pesaing dalam dunia perdagangan, maka perlu inovasi-inovasi baru untuk menumbuhkan kreativitas baru.

Dari pengamatan pendahuluan serta koordinasi dengan pengurus Desa Karang Pandan, Kelurahan Gilingan, Kecamatan Karang Pandan, Tim pengabdian kepada masyarakat memperoleh kesimpulan sebagai berikut : Bahwa masyarakat yang memiliki usaha kecil menengah (UKM) telah bekerja sebagai pedagang, namun hasilnya belum mencukupi kebutuhan sehari hari belum maksimal, hal tersebut dikarenakan modal paspasan. Modal yang mereka dapat biasanya dari lembaga keungan bukan dari koperasi yang memberikan bunga tinggi.

Peningkatan kesejahteraan ekonomi rakyat harus ditingkatkan oleh pelaku usaha itu sendiri dan dibantu oleh lembaga - lembaga keuangan yang memiliki penghasilan pada para pengusaha kecil.

Di Karang Pandan para pengusaha kecil membuat beberapa produknya diantaranya : Rambak, Tempe Kripik, Telur Puyuh, usaha tersebut sudah berlangsung beberapa tahun, namun keuntungan masih sedikit belum dapat dirasakan hasilnya, oleh karena itu kami Tim Pengabdian kepada Masyarakat STIE AUB SURAKARTA, merasa terpanggil untuk mengadakan penyuluhan pembentukan pra-koperasi dengan bantuan dari ibu-ibu PKK Desa Karang Pandan.

Selain itu perlu adanya kerja sama dan pelatihan tentang pembukuan uang benar sesuai teori-teori dalam akuntansi dan pengelolaan manajemen kredit yang benar. Mengingat pembukuan mereka masih sederhana serta pengelolaan tentang kredit yang baik sesuai dengan aturan-aturan yang benar.

\section{METODE}

Sasaran yang tepat dalam kegiatan ini adalah masyarakat yang terdiri dari kelompok pengusaha kecil dan menengah (UMKM) Desa Karang Pandan, Kecamatan Karang Pandan, Kabupaten Karanganyar. Pendekatan yang diberikan penduduk yaitu untuk pemecahan masalah adalah dengan memberikan pelatihan, pelatihan dapat berupa :

- Memberikan pemahaman hak dan kewajiban sebagai anggota koperasi.

- Memberikan pemahaman cara mendirikan koperasi.

- Memberikan pemahaman system pembukuan simpan pinjam.

- Memberikan pemahaman tentang pengelolaan keuangan rumah tangga.

Dalam pengabdian masyarakat di Desa Karang Pandan ini Tim pengabdian mengawali terlebih dahulu dengan observasi, mengenali keadaan/situasi lapangan/obyek yang akan digunakan pengabdian, maka selanjutnya mempelajari masalah-masalah apa saja yang ada di lapangan dan bagaimana membantu memecahkan masalah dengan menggunakan teori-teori atau ilmu-ilmu yang sesuai disiplin ilmu tim pengabdian.

Langkah - langkah yang perlu dilaksanakan dan metode - metode yang dapat membantu permasalahan di Desa Karang Pandan adalah sebagai berikut :

- Menyampaikan materi berupa makalah pada peserta/kelompok masyarakat.

- Memberikan pelatihan pembukuan simpan pinjam pada peserta kelompok yang hadir pada acara penyuluhan dari tim pengabdian.

- Memberikan pelatihan cara perhitungan SHU (Sisa Hasil Usaha) apabila nanti terbentuk badan koperasi.

- Memberikan pelatihan bagaimana cara pengelolaan keuangan rumah tangga, sehingga manajemen keuangan dapat tertata dengan baik secara efisien dan efektif. 


\section{PEMBAHASAN}

Pengabdian masyarakat yang dilakukan di Desa Karang Pandan ada beberapa cara, yaitu pertama wawancara pada masyarakat, masalah - masalah apa yang timbul di Kampung tersebut, langkah - langkah selanjutnya tim pengabdian kepada masyarakat berusaha membantu memberikan solusi untuk memecahkan masalah adalah sebagai berikut :

1. Strategi pemasaran pada pedagang kecil yang tergabung dalam kelompok UKM masih belum sesuai dengan teori - teori pemasaran.

2. Pendapatan para pedagang tersebut masih kurang keuntungannya.

3. Pengembangan produk masih perlu perhatian, baik secara kualitas dan kuantitas.

4. Variasi produk belum sepenuhnya berkembang.

5. Pedagang belum memahami dan mengetahui bagaimana cara berkomunikasi yang efektif dalam dunia perdagangan (Bisnis).

6. Kelompok UKM belum dikelola secara baik dari segi : Produk, manajemen keuangan, dan pemasaran.

Bertolak dari hal tersebut di atas maka tim pengabdian masyarakat berusaha memecahkan permasalahan-permasalahan tersebut :

Ad.1 Strategi pemasaran yang digunakan para pedagang dalam kelompok UKM taraf masih sangat sederhana belum sempurna, oleh karena itu pula diberi penyuluhan-penyuluhan dan pelatihan - pelatihan tentang cara menggunakan teori - teori pemasaran yang benar sesuai situasi dan kondisi pasar dan lokasi pedagang.

Ad.2 Pendapatan keuntungan

pedagang masih kurang, hal ini berkaitan dengan modal yang pas-pasan dan cara memasarkan yang sederhana serta kualitas produk yang kurang, oleh karena itu perlu adanya lembaga yang membantu kelompok UKM tersebut. Keuangan cara memasarkan yang kurang efektif juga berpengaruh terhadap keuntungan/laba yang masuk. Kualitas produk juga mempengaruhi keuntungan pedagang, karena konsumen akan mencari pedagang lain walaupun bentuk produk sama.

Ad. 3 Pengembangan produk sangat berpengaruh terhadap lakunya dagangan, oleh karena itu seorang pedagang perlu belajar terus agar produk bervariasi dan diminati pelanggan. Mengingat sekarang persaingan bisnis semakin banyak, pedagang harus peka terhadap situasi pasar demi kebutuhan konsumen atau keinginan konsumen.

Ad. 4 Variasi produk, merupakan faktor penting dalam keberhasilan bisnis, mengingat konsumen adalah manusia yang memiliki rasa tidak pernah puas, oleh karena itu pedagang perlu mencari inovasi-inovasi baru dalam membuat produk lebih menarik berbeda dengan produk yang sudah dibuat.

Ad. 5 Komunikasi sangat

mempengaruhi keberhasilan suatu bisnis, komunikasi pedagang dengan konsumen apabila terjadi dengan efektif dan berlangsung secara intens (ajeg) akan berpengaruh dalam lancarnya alur bisnis, karena keuntungan akan terus di peroleh bahkan dapat bertambah karena konsumen merasa dihargai dan dilayani dengan baik.

Ad. 6 Pengelolaan UKM yang baik mempengaruhi kehidupan bisnis para anggota anggotanya, oleh karena itu diperlukan kepengurusan yang dapat memperhatikan kebutuhan anggota - anggotanya.

Kelompok UKM di Desa tersebut masih mengalami hambatan, diantaranya adalah modal yang pas-pasan, belum adanya lembaga keuangan yang membantu belum terbentuknya koperasi. Pengelolaan keuangan, proses pembuatan produk, sampai pemasaran yang masi bersifat sederhana, tanpa menggunakan penghitungan yang jelas, tanpa menggunakan pembukuan yang benar, sehingga bisnis yang sudah lama 
terbentuk kurang dapat berkembang pesat, maka hal ini yang menjadi perhatian Tim pengabdian masyarakat untuk membantu agar usaha dagang pada kelompok UMKM bisa lebih berkembang, dengan memberikan penyuluhan, pelatihan cara memasarkan produk yang benar, sehingga keuntungan meningkat.

\section{PERILAKU KONSUMEN}

\section{BERPENGARUH}

Perilaku konsumen memiliki kepentingan khusus bagi orang karena berbagai alasan berhasrat mempengaruhi atau mengubah perilaku itu, termasuk mereka yang kepentingan utamanya adalah pemasaran, pendidikan, dan perlindungan konsumen, serta kebijakan umum.

Elemen kunci dalam definisi ini adalah pertukaran antara pelanggan dan penyuplai. Masing - masing pihak memberikan sesuatu yang bernilai kepada pihak lain dengan tujuan memenuhi kebutuhan mereka masing - masing. Dalam konteks pembelian yang normal, uang ditukar dengan barang atau jasa yang diinginkan.

Perhatikan bahwa pelanggan terletak pada inti dari proses tersebut. Semua yang dilakukan penyulpai dalam hal produk, harga, promosi dan distribusi diadaptasikan dengan permintaan pasar. Oleh karena itu pelanggan menjalankan pengaruh dominan pada semua yang dilakukan perusahaan. Tidak mengherankan bahwa studi perilaku konsumen memiliki akar utamanya di dalam bidang ekonomi, dan yang lebih baru, dalam bidang pemasaran. Dalam makalah ini akan dibahas tentang konsep dasar perilaku konsumen yang akan penulis paparkan dalam bab selanjutnya.

\section{TUJUAN PEMBAHASAN}

1. Untuk mengetahui manfaat dan tujuan yang diperoleh produsen dalam memperhatikan perilaku konsumen.

2. Untuk mengetahui arti dari perilaku konsumen dan faktor-faktor yang mempengaruhi perilaku konsumen.

3. Untuk mengetahui strategi pemasaran yang tepat untuk menciptakan keputusan pembelian pada konsumen.

4. Untuk mengetahui masalah apa saja yang sering dihadapi dalam melakukan Analisis Perilaku Konsumen.

\section{MANFAAT PENULISAN}

1. Hasil penulisan makalah ini dapat dijadikan sumber informasi dan masukan bagi produsen guna untuk meningkatkan jumlah penjualan produk mereka.

2. Hasil penulisan makalah ini diharapkan dapat menambah wawasan dan pemahaman penulis tentang alasan produsen perlu memahami perilaku konsumen dan hal-hal apa yang perlu diperhatikan produsen dalam memperhatikan perilaku konsumen.

\section{Pengertian Perilaku Konsumen}

Pada dasarnya perilaku konsumen merupakan tindakan atau perilaku, termasuk di dalamnya aspek-aspek yang mempengaruhi tindakan itu, yang berhubungan dengan usaha untuk mendapatkan produk (barang dan jasa) guna memenuhi kebutuhannya. Tidak ada kesamaan definisi yang dikemukakan para ahli, perbedaan itu disebabkan adanya perbedaan 
sudut pandang. Perilaku manusia sangat komplek sehingga sangat sulit digambarkan dengan kata - kata.

Perilaku konsumen adalah "Consumer behavior can be defined as the behavior that customer display in searching for, purchasing, using, evaluating, and disposintog of products, services, and ideas they expect will satisfy they needs". Pengertian tersebut berarti perilaku yang diperhatikan konsumen dalam mencari, membeli, menggunakan, mengevaluasi dan mengabaikan produk, jasa, atau ide yang diharapkan dapat memuaskan konsumen untuk dapat memuaskan kebutuhannya dengan mengkonsumsi produk atau jasa yang ditawarkan.

Perilaku konsumen adalah "Consumer behavior may be defined as the decision process and physical activity individuals engange in when evaluating, acquiring, using, or disposing of goods an services". Dapat dijelaskan perilaku konsumen adalah proses pengambilan keputusan dan kegiatan fisik individu - individu yang semuanya ini melibatkan individu dalam menilai, mendapatkan, menggunakan, atau mengabaikan barang-barang dan jasa- jasa.

Perilaku konsumen adalah tindakan yang langsung terlibat dalam mendapatkan, mengkonsumsi, dan menghabisakn produk dan jasa, termasuk proses yang mendahului dan menyusul dari tindakan ini.

Perilaku konsumen adalah study unit-unit dan proses pembuatan keputusan yang terlibat dalam menerima, menggunakan dan penentuan barang, jasa, dan ide. Definisi tersebut menggunakan istilah unit-unit pembuat keputusan, karena keputusan bisa dibuat oleh individu atau kelompok. Definisi tersebut juga mengatakan bahwa konsumsi adalah proses yang diawali dengan penerimaan, konsumsi, dan diakhiri dengan penentuan (disposition). Tahap penerimaan menganalisa faktor-faktor yang mempengaruhi pilihan konsumen terhadap produk, tahap konsumsi menganalisa bagaimana konsumen senyatanya menggunakan produk yang diperoleh. Tahap penentuan menunjukkan apa yang dilakukan konsumen setelah selesai menggunakan produk tersebut. Studi perilaku konsumen ini meliputi : Apa yang dibeli, mengapa ia membelinya, dan berapa sering ia membelinya.

Secara umum, definisi dari perilaku konsumen adalah "Interaksi dinamis antara pengaruh dan kognisi, perilaku, dan kejadian disekitar kita, dimana terdapat aspek pertukaran didalamnya". Dari definisi umum tersebut, dapat diambil kesimpulan bahwa terdapat tiga faktor penting didalam definisi tersebut, yaitu perilaku konsumen adalah dinamis, melibatkan interaksi antara pengaruh dan kognisi, perilaku dan kejadian sekitar, serta adanya aspek pertukaran.

1. Dinamis

Dinamis artinya bahwa seorang individu konsumen, suatu konsumen, atau masyarakat luas akan selalu berubah dan bergerak sepanjang waktu. Hal ini berdampak tidak hanya pada studi perilaku konsumen itu sendiri akan tetapi juga pada pengembangan strategi pemasaran.

2. Melibatkan Interaksi antara Pengaruh (afeksi) dan Kognisi, Perilaku dan Kejadian Sekitar.

Untuk memahami konsumen dan mengembangkan strategi pemasaran kita harus memahami apa yang dipikirkan (kognisi) apa yang dirasakan (afeksi) dan apa yang mereka lakukan serta kejadian sekitar yang mempengaruhi dan dipengaruhi oleh apa yang dipikirkan, dirasa, dan dilakukan konsumen.

3. Adanya Aspek Pertukaran

\section{Teori Perilaku Konsumen}

Ada beberapa teori-teori yang mendasari perilaku konsumen terhadap produk yang ada, yakni : 
1. Teori Ekonomi Mikro

Teori ini beranggapan bahwa setiap konsumen akan berusaha memperoleh kepuasan maksimal. Mereka akan berupaya meneruskan pembeliannya terhadap suatu produk apabila memperoleh kepuasan dari produk yang telah dikonsumsinya, dimana kepuasan ini sebanding atau lebih besar dengan marginal utility yang diturunkan dari pengeluaran yang sama untuk beberapa produk yang lain.

2. Teori Psikologis

Teori ini mendasarkan diri pada faktor-faktor psikologis individu yang dipengaruhi oleh kekuatan-kekuatan lingkungan. Bidang psikologis ini sangat kompleks dalam menganalisa perilaku konsumen, karena proses mental tidak dapat diamati secara langsung.

3. Teori Antropologis

Teori ini juga menekankan perilaku pembelian dari suatu kelompok masyarakat yang ruang lingkupnya sangat luas, seperti kebudayaan, kelas-kelas sosial dan sebagainya.

\section{Analisis Pemahaman Perilaku}

\section{Konsumen}

Perilaku konsumen menitikberatkan pada aktivitas yang berhubungan dengan konsumsi dari individu. Perilaku konsumen berhubungan dengan alasan dan tekanan yang mempengaruhi pemilihan, pembelian, penggunaan, dan pembuangan barang dan jasa yang bertujuan untuk memuaskan kebutuhan dan keinginan pribadi.

Berdasarkan definisi di atas dapat disimpulkan bahwa perilaku konsumen adalah tindakan-tindakan yang dilakukan oleh individu, kelompok atau organisasi yang berhubungan dengan proses pengambilan keputusan dalam mendapatkan, menggunakan barang-barang atau jasa ekonomi yang selalu berubah dan bergerak sepanjang waktu.

Menurut Handi Irawan, Perilaku Konsumen Indonesia dikategorikan menjadi sepuluh, yaitu :

1. Berpikir Jangka Pendek (short term perspective)

Ternyata sebagian besar konsumen Indonesia hanya berpikir jangka pendek dan sulit untuk diajak berpikir jangka panjang, salah satu cirinya adalah dengan mencari yang serba instant.

2. Tidak Terencana (dominated by unplanned behavior)

Hal ini tercermin pada kebiasaan impulse buying, yaitu membeli produk yang kelihatan menarik tanpa ada perencanaan sebelumnya.

3. Suka Berkumpul

Masyarakat Indonesia mempunyai kebiasaan suka berkumpul (sosialisasi). Salah satu indicator terkini adalah situs social networking seperti Facebook dan Twitter sangat diminati dan digunakan secara luas di Indonesia.

4. Gagap Teknologi (not adaptive to high technology)

Sebagian besar konsumen Indonesia tidak begitu menguasai teknologi tinggi. Hanya sebatas pengguna biasa dan hanya menggunakan fitur yang umum digunakan kebanyakan pengguna lain.

5. Berorientasi pada Konteks (context, not content oriented)

Konsumen kita cenderung menilai dan memilih sesuatu dari tampilan luarnya. Dengan begitu, konteks-konteks yang meliputi suatu hal justru lebih menarik ketimbang hal itu sendiri.

6. Suka Buatan Luar Negeri (receptive to COD effect) 
Sebagian konsumen Indonesia juga lebih menyukai produk luar negeri daripada produk dalam negeri, karena bisa dibilang kualitasnya juga lebih bagus dibanding produk di Indonesia.

7. Beragama (religious)

Konsumen Indonesia sangat peduli terhadap isu agama. Inilah salah satu karakter khas konsumen Indonesia yang percaya pada ajaran agamanya. Konsumen akan lebih percaya jika perkataan itu dikemukakan oleh seorang tokoh agama, ulama atau pendeta. Konsumen juga suka dengan produk yang mengusung symbol-simbol agama.

8. Gensi (putting prestige as important motive)

Konsumen Indonesia amat getol dengan gengsi. Banyak yang ingin cepat naik "status" walau belum waktunya. Saking pentingnya urusan gengsi ini, mobil-mobil mewah pun tetap laris terjual di negeri kita pada saat krisis ekonomi sekalipun. Menurut Handi Irawan D, ada tiga budaya yang menyebabkan gengsi. Pertama : Konsumen Indonesia suka bersosialisasi sehingga menciptakan mendorong orang untuk pamer. Kedua : Budaya feudal yang masih melekat sehingga menciptakan kelas-kelas sosial dan akhirnya terjadi "pemberontakan" untuk cepat naik kelas. Ketiga : Masyarakat kita mengukur kesuksesan dengan materi dan jabatan sehingga mendorong untuk saling pamer.

9. Budaya Lokal (strong in subculture)

Sekalipun konsumen Indonesia gengsi dan menyukai produk luar negeri, namun unsur fanatisme kedaerahan-nya ternyata cukup tinggi. Ini bukan berarti bertentangan dengan hokum perilaku yang lain.

10. Kurang peduli lingkungan (low consciousness towards environment)

Salah satu karakter konsumen Indonesia yang unik adalah kekurang pedulian mereka terhadap isu lingkungan. Tetapi jika melihat prospek kedepan kepedulian konsumen terhadap lingkungan akan semakin meningkat, terutama mereka yang tinggal di perkotaan begitu pula dengan kalangan menengah atas relatif lebih mudah paham dengan isu lingkungan. Lagi pula mereka pun memiliki daya beli terhadap harga premium sehingga akan lebih mudah memasarkan produk dengan tema ramah lingkungan terhadap mereka.

\section{Pendekatan Perilaku Konsumen}

Teori perilaku konsumen dapat dibedakan dalam dua macam pendekatan yaitu sebagai berikut :

1. Pendekatan Nilai Guna Kardinal

Pendekatan nilai guna kardinal atau sering disebut dengan teori nilai subyektif menganggap manfaat atau kenikmatan yang diperoleh seorang konsumen dapat dinyatakan secara kuantitatif/dapat diukur, dimana keseimbangan konsumen dalam memaksimumkan kepuasan atas konsumsi berbagai macam barang, dilihat dari seberapa besar uang yang dikeluarkan untuk membeli unit tambahan dari berbagai jenis barang akan memberikan nilai guna marginal yang sama besarnya. Oleh karena itu keseimbangan konsumen dapat dicari dengan pendekatan kuantitatif. Kepuasan seorang konsumen dalam mengkonsumsi suatu barang dapat diukur dengan satuan kepuasan. Misalnya : mata uang. Setiap tambahan satu unit barang yang dikonsumsi akan menambah kepuasan yang diperoleh konsumen tersebut dalam jumlah tertentu.

2. Pendekatan Nilai Guna Ordinal

Pendekatan nilai guna ordinal atau sering juga disebut analisis kurva indeference menganggap bahwa manfaat yang diperoleh masyarakat dari mengkonsumsikan 
barang-barang tidak kuantitif/tidak dapat diukur. Pendekatan ini muncul karena adanya keterbatasan - keterbatasan yang ada pada pendekatan cardinal, meskipun bukan berarti pendekatan cardinal tidak memiliki kelebihan. Kepuasan konsumen dari mengkonsumsi barang dapat diukur dengan satuan kepuasan. Pada kenyataannya pengukuran semacam ini sulit dilakukan.

3. Persamaan Nilai Guna Kardinal dengan Ordinal

Persamaan Kardina dan Ordinal yaitu sama - sama menjelaskan tindakan konsumen dalam mengkonsumsi barang-barang yang harganya tertentu dengan pendapatan konsumen yang tertentu pula agar konsumen mencapai tujuannya (maximum utility).

4. Perbedaan Nilai Guna Kardinal dengan Ordinal

Nilai guna cardinal menganggap bahwa besarnya utility dapat dinyatakan dalam bilangan/angka. Sedangkan analisis ordinal, besarnya utility dapat dinyatakan dalam bilangan/angka. Analisis cardinal menggunakan alat analisis yang dinamakan pendekatan marginal (marginal utility). Sedangkan analisis ordinal menggunakan analisis kurva kepuasan sama (indifferent curve).

\section{Hubungan Pemasaran dan Perilaku Konsumen}

Pengertian Pemasaran menurut Stanton adalah suatu system keseluruhan dari kegiatan-kegiatan bisnis yang ditujukan untuk merencanakan, menentukan harga, mempromosikan, dan mendistribusikan barang dan jasa untuk memuaskan kebutuhan, baik kepada pembeli yang ada maupun pembeli potensial (Stanton, 1997). Pengertian tersebut dapat memberikan gambaran bahwa pemasaran sebagai suatu system dari kegiatan-kegiatan yang saling berhubungan, ditujukan untuk merencanakan, menentukan harga, mempromosikan, dan mendistribusikan barang/jasa kepada pembeli secara individual maupun kelompok pembeli.

Kegiatan-kegiatan tersebut beroperasi dalam suatu lingkungan yang dibatasi sumber-sumber dari perusahaan itu sendiri, paraturan-peraturan, maupun konsekuensi sosial perusahaan. Pengertian pemasaran menurut Kotler $(2000: 8)$, pemasaran adalah proses sosial dan manajerial dimana individu dan kelompok mendapatkan apa yang mereka butuhkan dan inginkan dengan menciptakan, menawarkan dan mempertukarkan produk dengan pihak lain. Dalam hal ini pemasaran merupakan proses pertemuan individu dan kelompok dimana masing masing pihak ingin mendapatkan apa yang mereka butuhkan/inginkan melalui tahap menciptakan,menawarkan, dan pertukaran. Definisi pemasaran tersebut berdasarkan pada prinsip inti yang meliputi: kebutuhan (need), produk (goods, service and idea), permintaan (demands), nilai biaya, kepuasan, pertukaran, transaksi, hubungan, dan jaringan, pasar, pemasar, serta prospek.

Terdapat dua faktor yang mempengaruhi cara dan keberhasilan perusahaan terhadap pemasarannya, yaitu:

1) Lingkungan Eksternal Sistem Pemasaran. Lingkungan ini tidak dapat dikendalikan perusahaan, misalnya kebebasan masyarakat dalam menerima atau menolak produk perusahaan, politik dan peraturan pemerintahan, keadaan perkonomian, kependudukan serta munculnya pesaing.

2) Variable Internal System Pemasaran. Variabel ini dapat dikendalikan oleh perusahaan, terdiri atas dua kelompok, yaitu sumber bukan pemasaran (kemampuan produksi,keuangan, dan personal) dan komponen-kompenen bauran pemasaran yang meliputi : produk, harga, promosi, dan distribusi (swastha, 2002).

Perilaku Konsumen adalah kegiatan-kegiatan individu yang secara langsung terlibat dalam mendapatkan dan menggunakan barang dan jasa termasuk di dalamnya proses pengambilan keputusan pada persiapan dan penentuan kegiatan-kegiatan tersebut 
(swasta dkk.,1997). Perilaku konsumen mempelajari di mana, dalam kondisi macam apa, dan bagaimana kebiasaan seorang membeli produk tertentu dengan merk tertentu. Kesemuanya ini sangat membantu manager permasaran di dalam menyusun kebijaksanaan pemasaran perusahaan.

\section{DAFTAR PUSTAKA}

Sudirman, Ari. 2000. “Teori Ekonomi Mikro” Buku 1. Yogyakarta: BPFE.

Engel, James F, Black Well Roger D, Miniard Paul W. 1994. Perilaku Konsumen. Jakarta: Binarupa Aksara.

Dr Wijaya, Faried, M.M.A. pengantar Ekonomi - Ekonomika Pembnagnunan dan Internasinonal. Edisi Kedua, Jilid Kedua. Yogyakarta: BPFE UGM.

Paul A. Samuelson, William D. Norddhaus. Ekonomi. Edisi keduabelas. 1997. Jakarta: Penerbit Erlangga.

Rosyidi Suherman. Pengantar Teori Ekonomi - Pendekatan Kepada Teori Ekonomi Mikro dan Makro. Jakarta: PT RajaGrafindo Persada.

Mangkoesoebroto, Guritno. 1993. "Ekonomi Publik. "Yogyakarta: BPFE. 